\title{
Comparison of total column ozone obtained by the IASI-MetOp satellite with ground-based and OMI satellite observations in the southern tropics and subtropics
}

\author{
A. M. Toihir ${ }^{1}$, H. Bencherif ${ }^{1}$, V. Sivakumar ${ }^{2}$, L. El Amraoui ${ }^{3}$, T. Portafaix ${ }^{1}$, and N. Mbatha ${ }^{4}$ \\ ${ }^{1}$ Laboratoire de l'Atmosphère et des Cyclones, Université de La Réunion, St-Denis, Réunion Island, France \\ ${ }^{2}$ School of Chemistry and Physics, University of KwaZulu Natal, Durban, South Africa \\ ${ }^{3}$ Centre National de Recherche Météorologique, Météo-France, Toulouse, France \\ ${ }^{4}$ South African Weather Service, P.O. Box 320, Stellenbosch 7599, South Africa
}

Correspondence to: A. M. Toihir (mohamed.abdoulwahab@univ-reunion.fr)

Received: 14 May 2015 - Revised: 19 August 2015 - Accepted: 24 August 2015 - Published: 16 September 2015

\begin{abstract}
This paper presents comparison results of the total column ozone (TCO) data product over 13 southern tropical and subtropical sites recorded from the Infrared Atmospheric Sounder Interferometer (IASI) onboard the EUMETSAT (European organization for the exploitation of METeorological SATellite) MetOp (Meteorological Operational satellite program) satellite. TCO monthly averages obtained from IASI between June 2008 and December 2012 are compared with collocated TCO measurements from the Ozone Monitoring Instrument (OMI) on the OMI/Aura satellite and the Dobson and SAOZ (Système d'Analyse par Observation Zénithale) ground-based instruments. The results show that IASI displays a positive bias with an average less than $2 \%$ with respect to OMI and Dobson observations, but exhibits a negative bias compared to SAOZ over Bauru with a bias around $2.63 \%$. There is a good agreement between IASI and the other instruments, especially from $15^{\circ} \mathrm{S}$ southward where a correlation coefficient higher than 0.87 is found. IASI exhibits a seasonal dependence, with an upward trend in autumn and a downward trend during spring, especially before September 2010. After September 2010, the autumn seasonal bias is considerably reduced due to changes made to the retrieval algorithm of the IASI level 2 (L2) product.

The $\mathrm{L} 2$ product released after August (L2 $\mathrm{O}_{3}$ version 5 (v5)) matches TCO from the other instruments better compared to version 4 (v4), which was released between June 2008 and August 2010. IASI bias error recorded from September 2010 is estimated to be at $1.5 \%$ with respect to OMI and less than $\pm 1 \%$ with respect to the other ground-
\end{abstract}

based instruments. Thus, the improvement made by $\mathrm{O}_{3} \mathrm{~L} 2$ version 5 (v5) product compared with version 4 (v4), allows IASI TCO products to be used with confidence to study the distribution and interannual variability of total ozone in the southern tropics and subtropics.

Keywords. Atmospheric composition and structure (middle atmosphere - composition and chemistry)

\section{Introduction}

Atmospheric ozone plays a key role since it protects the biosphere from harmful ultraviolet radiation. About $90 \%$ of its mass is found in the stratosphere where ozone is formed through photochemical reactions. Most ozone is formed in the tropics but is rapidly transported to higher latitudes by Brewer-Dobson large-scale circulation (Weber et al., 2011). Global total column ozone (TCO) has depleted gradually since 1980 with an increase of chlorofluorocarbon concentrations in the stratosphere due to anthropogenic activities. Ozone is under high surveillance, especially since the discovery of the Antarctic ozone hole (Farman et al., 1985; Krueger et al., 1992; Stolarski et al., 1990). In 1987, the Montreal protocol was formulated in order to regulate the emissions of substances that deplete ozone (United Nations Environment Programme UNEP, 2009); thus we have been expecting an increase in ozone by now. So validation of new measurements is of paramount importance. In recent years, different observations and studies have shown that subtropical 
dynamic processes such as vertical and isentropic exchanges through the southern stratospheric dynamical barriers contribute to the transport and variability of ozone (Portafaix et al., 2003; El Amraoui et al., 2010; Bencherif et al., 2007, 2011). Moreover, latest reports on ozone assessment seem to fear a delay in the recovery of ozone in the tropics due to an acceleration of Brewer-Dobson circulation (WMO/UNEP, 2014). Based on the above facts, it is important to monitor and survey total ozone continuously in the southern tropics and subtropics.

Different remote sensing technics are currently used to retrieve total ozone information. Alongside remote sensing observations, measuring devices from ground-based instruments and high technology instruments on board satellites are used. Most ground-based instruments operate in ultraviolet wavelength band and/or are visible, such as BrewerDobson and SAOZ (Système d'Analyse par Observation Zénithale), while others, such as the FTIR (Fourier Transform infrared) spectrometer, operate in the infrared spectrum. Different techniques and spectral band used by satellite instruments are also used for ozone measurements, depending on the device used. Though satellite measurements offer the best method for providing TCO measurements over the globe with good spatial coverage, their spectral and temporal resolution are poor in comparison to most ground-based instruments. It is therefore necessary to compare the satellite measurements with ground-based measurements in order to assess the quality of the satellite observations.

In the framework of satellite observations, the Meteorological Operational satellite program (MetOp) is a European polar orbiting satellite which aims to provide weather information services and monitor climate (Edwards et al., 2006). The Infrared Atmospheric Sounding Interferometer (IASI) is one of the instruments onboard the MetOp launched in October 2006, dedicated among other products to the global observation of TCO. It is necessary to evaluate the accuracy of measurements prior to applying them for any major scientific purpose.

In the framework of assessment of TCO products, Bracher et al. (2005) validated global stratospheric ozone column measured by the SCanning Imaging Absorption spectroMeter for Atmospheric CHartographY (SCIAMACHY) onboard the Environment Satellite (ENVISAT) using observations from GOME (Global Ozone Monitoring Experiment) satellite instrument. OMI (Ozone Monitoring Instrument) TCO product validation has been performed using observations from Dobson and Brewer ground-based instruments (Balis et al., 2007a). Similarly, Kroon et al. (2006) validated OMITOMS (Total Ozone Mapping Spectrometer) overpass products by comparing them with the Dobson over- collocated stations; through this validation study the authors found an average bias of $1 \%$ between the two instruments if the tropics are excluded. Numerous papers have reported that TCO from the TOMS instrument is assessed based on comparative studies with ground-based network stations (Balis et al., 2007b; McPeters and Labow 1996; Bramstedt et al., 2003). In the framework of the TOMS product assessment, Bramstedt et al. (2003) reported that TOMS V7 tends to overestimate total ozone over the Southern Hemisphere by more than $2 \%$ on average. Recently an improved version of TCO is retrieved from SAOZ after calculating the $\mathrm{O}_{3}$ airmass factor (AMF) using the TOMS V8 climatological profiles. TV8 profiles consist of a monthly mean climatology for $10^{\circ}$ bands between $90^{\circ} \mathrm{S}$ and $90^{\circ} \mathrm{N}$, covering altitudes from 0 to $60 \mathrm{~km}$ (Hendrick et al., 2011). TV8 was built by combining profile data from SAGE II (Stratospheric Aerosol and Gas Experiment II), MLS (Microwave Limb Sounder), and ozone-sonde. The improved SAOZ product was compared with products from TOMS, GOME, SCIAMACHY and OMI overpass NDACC (Network for the Detection of Atmospheric Composition Change) collocated stations and a good agreement was observed between $\mathrm{SAOZ}$ and satellite observations (Hendrick et al., 2011; Pastel et al., 2014). However, a systematic seasonal dependence is recorded on SAOZ measurements (Hendrick et al., 2011). In this way, the comparison of ozone products obtained from IASI with measurements obtained from other satellites and ground-based spectrometers is important for improving and ensuring the IASI observations' quality. Therefore, ozone measurements from IASI have recently been compared with other measurements from ground-based and satellite instruments (Antón et al., 2011; Boynard et al., 2009; Keim et al., 2009), but the selected ground-based stations for the validation surveys are mostly located in the Northern Hemisphere. It is thus necessary to conduct a similar study for the Southern Hemisphere tropics and subtropics. The purpose of this paper is to examine and validate the TCO recorded by IASI from June 2008 to December 2012 over 13 sites located in the southern tropics and subtropics (see Fig. 1). The present work discusses the behaviour of IASI/MetOp-A measurements with respect to measurements from ground-based (Dobson or SAOZ) and satellite (OMI) instruments in the tropical and subtropical regions and for individual sites as well. However, the possible sources of difference or agreement observed between instruments are not widely discussed and would probably be better explored in a separate, subsequent scientific paper.

This paper is organized as follows: Sect. 2 provides a brief description of each instrument and data used, followed by the method of analysis in Sect. 3. Results and discussion based on the comparison of temporal and spatial distributions of TCO monthly means from the IASI with those from groundbased instruments and the OMI satellite instrument are presented in Sect. 4. Finally, a summary and conclusions are presented in Sect. 5.

\section{Data source}

The TCO products from IASI and OMI are used in this study; more details are given below. It is important to note that both instruments provide global observations in the nadir view 


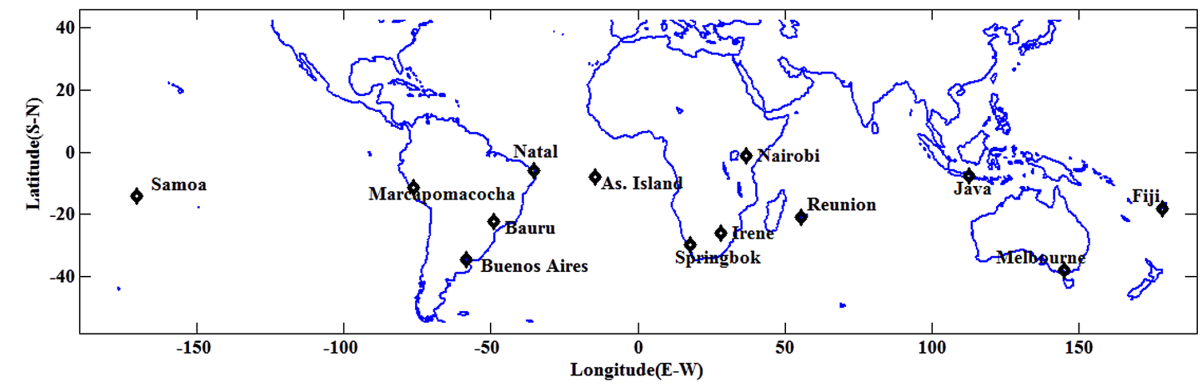

Figure 1. Geolocations of the 13 stations in the Southern Hemisphere selected for this study.

from a polar heliosynchronous orbit. Ground-based measurements were made using Dobson and SAOZ instruments. These data were obtained from the World Ozone and Ultraviolet Data Center (WOUDC) website http://woudc.org/.

\subsection{IASI}

\subsubsection{IASI/MetOp-A instrument and objective}

IASI/MetOp-A is a nadir-viewing Fourier Transform spectrometer (FTS) onboard the meteorological operational (MetOp) satellite of the European organization for the exploitation of METeorological SATellite (EUMETSAT); launched on October 2006, orbiting at $817 \mathrm{~km}$ and crossing the equatorial plane at two fixed local solar times during descending (ascending) mode at 09:30 (21:30) (Boynard et al., 2009). IASI is a thermal infrared spectrometer designed to measure the spectrum emitted by the Earth's atmosphere system, with a spectral resolution between 0.3 and $0.5 \mathrm{~cm}^{-1}$ in the spectral range from 645 to $2760 \mathrm{~cm}^{-1}$ (Clerbaux et al., 2009; Massart et al., 2009; Turkety, et al., 2004; Antón et al., 2011). Hence, IASI has the ability to provide radiative information of cloud, temperature and humidity profiles and profiles of many chemical species that are sensitive to infrared absorption bands such as $\mathrm{CO}, \mathrm{O}_{3}, \mathrm{CO}_{2}, \mathrm{~N}_{2} \mathrm{O}$ and $\mathrm{CH}_{4}$. However, we have only used $\mathrm{O}_{3}$ measurements for the present study. Ozone is retrieved from the $9.6 \mu \mathrm{m}$ absorption band and the instrumental radiometric noise is evaluated to be less than $0.2 \mathrm{~K}$ at $280 \mathrm{~K}$. Regarding the spatial resolution, IASI operates with an angle of view evaluated at $48.3^{\circ}$ maximum which covers a swath width of $\sim 2200 \mathrm{~km}$. Each instantaneous field of view $(50 \mathrm{~km} \times 50 \mathrm{~km}$ at nadir) is composed of a matrix of $2 \times 2$ circular pixels, with a $12 \mathrm{~km}$ diameter.

\subsubsection{IASI ozone data}

Global observations are achieved twice per day and IASI data have provided these since May 2007 (August et al., 2012). Thus TCO is retrieved using different algorithms and the uncertainty is estimated to be $\sim 2.5 \%$ (Viatte et al., 2011). Actually more than three IASI ozone products from different algorithms are available (Dufour et al., 2012; Keim et al., 2009). Among the different products, one may find the LA (Labratoire d'Aérologie) product described by Barret et al. (2011), the LISA (Laboratoire Inter-universitaire des Systèmes Atmosphériques) product retrieved with a radiative transfer model called KOPRA (Karlsruhe Optimized and Precise Radiative transfer Algorithm) and the LATMOS/ULB (Laboratoire Atmosphère, Milieux, Observations Spatiales/Université Libre de Bruxelles) product obtained from the FORLI-O3 (Fast Optimal Retrievals on Layers for IASI) software (Hurtmans et al., 2012). However, the operational product is the IASI L2 PPF (product processing facility) developed by the IASI Sounding Science Working Group (ISSWG) under EUMETSAT supervision. The first publicly released data are found in version 4 (v4), which was available from June 2008 and has been replaced by version 5 (v5) from September 2010 up until now. It is worth noting that other EUMETSAT ozone L2 products have been developed based on a neural network retrieval algorithm (Turkety et al., 2004) which is observed to underestimate TCO compared to ground-based observations, especially over the Izaña station, where biases of -5.0 and $-0.9 \%$ are found with respect to FTIR and Brewer, respectively (Viatte et al., 2011). The ISSWG product is used in this present work for overpasses over 13 sites located in the southern tropics and subtropics (see. Fig. 1). We have used a radius of $2^{\circ}$ (longitude and latitude) to delimit the satellite overpass zone around each station. The daily mean ozone value is considered within the circular perimeter. The list of the selected stations and the respective geographic coordinates are given further in Table 1.

\subsubsection{The operational IASI level 2 products}

The different steps that are followed for IASI L2 retrieval can be summarized as follow: the first step is a pre-processing step aiming to configure the retrieval algorithm and to correct and validate the IASI measured spectrum. Indeed the L2 ingests two kinds of auxiliary data and the calibrated spectra stored in the IASI L1 product. The first type of auxiliary database is used for the algorithm retrieval configuration and to calculate the surface elevation, the land/sea fractional coverage and the land surface emissivity for each field of view. The second kind of auxiliary data consist of additional collocated measurements describing the state of the 
Table 1. Bias, absolute and relative RMS and correlation coefficient $R^{2}$ obtained from the comparative study between IASI and the other instruments (OMI, Dobson and SAOZ) over the subtropical and tropical selected sites. Comparison between IASI and SAOZ instruments is performed only for Réunion and Bauru stations, while the comparison between IASI and Dobson has been made for Marcapomacocha, Irene, Springbok, Buenos Aires and Melbourne stations.

\begin{tabular}{|c|c|c|c|c|c|c|c|c|}
\hline \multicolumn{3}{|c|}{ Stations } & \multicolumn{3}{|c|}{ IASI-OMI } & \multicolumn{3}{|c|}{ IASI - Dobson (or SAOZ) } \\
\hline & Lat. & Long. & RMS (DU) & $\%$ bias $(1 \sigma)$ & $R^{2}$ & RMS (DU) & $\%$ bias $(1 \sigma)$ & $R^{2}$ \\
\hline Nairobi & -1.27 & 36.80 & $6.93(2.7 \%)$ & $2.33(2.4)$ & 0.82 & & & \\
\hline Natal & -5.87 & -35.2 & $5.27(2.0 \%)$ & $0.40(2.6)$ & 0.78 & & & \\
\hline Java & -7.57 & 112.65 & $5.58(2.2 \%)$ & $1.57(2.3)$ & 0.63 & & & \\
\hline Ascension & -7.98 & -14.42 & $5.22(1.9 \%)$ & $-0.12(2.5)$ & 0.75 & & & \\
\hline Marcapomacocha & -11.40 & -76.32 & $12.12(5.0 \%)$ & $4.99(3.2)$ & 0.57 & $9.93(3.9 \%)$ & $3.43(3.3)$ & 0.41 \\
\hline Samoa & -14.23 & -170.50 & $7.24(2.8 \%)$ & $2.85(2.2)$ & 0.75 & & & \\
\hline Fiji & -18.13 & 178.40 & $6.27(2.5 \%)$ & $2.35(2.5)$ & 0.83 & & & \\
\hline La Réunion & -20.90 & 55.48 & $6.13(2.3 \%)$ & $0.25(2.8)$ & 0.84 & $5.66(2.1 \%)$ & $0.19(2.6)$ & 0.82 \\
\hline Bauru & -22.34 & -49.03 & $5.29(2.0 \%)$ & $1.25(2.2)$ & 0.85 & $8.47(3.0 \%)$ & $-2.65(2.5)$ & 0.76 \\
\hline Irene & -25.91 & 28.21 & $5.78(2.2 \%)$ & $1.16(2.5)$ & 0.86 & $7.12(2.6 \%)$ & $0.26(3.6)$ & 0.75 \\
\hline Springbok & -26.7 & 17.9 & $6.46(2.4 \%)$ & $1.21(2.8)$ & 0.85 & $7.10(2.5 \%)$ & $0.43(3.2)$ & 0.83 \\
\hline Buenos Aires & -34.58 & -58.48 & $7.74(2.7 \%)$ & $2.48(3.5)$ & 0.93 & $9.22(3.5 \%)$ & $3.12(2.9)$ & 0.93 \\
\hline Melbourne & -37.80 & 144.97 & $10.16(3.5 \%)$ & $3.09(3.5)$ & 0.94 & $9.51(3.6 \%)$ & $2.15(4.2)$ & 0.91 \\
\hline
\end{tabular}

atmosphere in near real time. These are NWP (numerical weather prediction) information from ECMWF (European Center for Medium-Range Weather Prediction) and other data proved by collocated instruments (Microwave Humidity Sounder (MHS), Advanced Microwave Sounding Unit (AMSU) and Advanced Very High Resolution Radiometer (AVHRR)) aboard the MetOp satellite. Both auxiliary data are involved in the validation of the IASI radiance and support the L2 retrieval. We invite the reader to consult Amato et al. (2002) for the code used to compute the IASI radiance. After the radiance computation, the radiance noise is filtered based on a principal component analysis (PCA) method (Kahn et al., 2004; Matricardi, 2010). This pre-processing step is well detailed by August et al. (2012) and by Schlüssel at al. (2005). The second step of processing is the cloud detection. This step is essential, because ozone L2 retrieval is performed only for clear sky; thus the contamination of undetected cloud leads to inaccuracy in the final L2 product quality. The ozone profile is retrieved for the cloud-free atmosphere based on linear EOF (empirical orthogonal function) regression (Calbet and Schlüssel, 2006). The technique consists of computing the principal component scores of the IASI radiance, then using them as input for the linear regression to determine the ozone profile. This statistical retrieval method (linear EOF regression) used to determine IASI L2 profile is discussed and validated by Calbet at al. (2006). The retrieved ozone profile by linear regression follows a final iterative process known as optimal estimation method (OEM). Full detail of this final processing can be found in August et al. (2012). It is worth noting that this final processing has been performed only on the IASI L2 PPF (product processing facility) version v5 whilst the retrieval of version $\mathrm{v} 4$ is limited to the linear EOF regression method. The additional step of processing is to integrate the obtained ozone profile to determine the total column ozone. The IASI TCO L2 used in this work is composed from both versions 4 and 5. Data recorded before September 2010 are from v4 and those after September 2010 have been retrieved following the PPF v5 structure.

The validation report of version 4 (George and Clerbeaux, 2010) indicates the variation of surface emissivity values in some regions of the globe, which contribute to the radiance spectra. The emissivity issue is observed especially in the spectral range, where ozone is strongly being absorbed and can affect the baseline of ozone retrieval significantly. In this validation report, authors evoked the presence of unidentified low clouds, whereas ozone retrieval is supposed to be under cloudless conditions. Thus the cloud contamination can degrade the quality of L2 ozone products. It is worth noting that in version $\mathrm{v} 4$, cloud detection relied only on the NWP cloud test (Pavelin et al., 2008). Because of emissivity and cloud issues observed on PPF L2 v4, two additional cloud detection tests, AVHRR cloud fraction (Schlüssel at al., 2005) and optical thickness test (Zhou et al., 2005, 2007) have been performed in PPF L2 v5. The adopted method to compute surface emissivity during PPF L2 v4 retrieval (Loveland et al., 2000) has been replaced by a better performing one, developed by Zhou et al. (2011) in order to improve ozone retrievals.

\subsection{OMI}

OMI is an instrument onboard the Aura satellite launched on 15 July 2004 into a near polar heliosynchronous orbit at an altitude of approximately $705 \mathrm{~km}$. OMI is a nadir- 
viewing spectrometer that measures atmospheric trace gas concentrations such as $\mathrm{O}_{3}$ and $\mathrm{N}_{2} \mathrm{O}$, as well as cloud and aerosol properties in three broad spectral regions (UV-1, UV2 and VIS). OMI has a spectral resolution of the order of $\sim 0.5 \mathrm{~nm}$. Regarding the spatial coverage, its viewing angle is $57^{\circ}$ under a swath width of $2600 \mathrm{~km}$; the ground pixel size of each scan is $13 \times 24 \mathrm{~km}^{2}$ in the UV-2 $(310-365 \mathrm{~nm})$ and visible $(350-500 \mathrm{~nm})$ channels, and $13 \times 48 \mathrm{~km}^{2}$ for the UV-1 $(270-310 \mathrm{~nm})$ channel. Among the principal objectives of the OMI instrument is to measure the total ozone amount in the atmosphere. Two types of TCO are available from OMI: the product obtained with the differential optical absorption spectroscopy (DOAS), commonly called OMIDOAS, and the other called OMI-TOMS, retrieved using the TOMS algorithm (Balis et al., 2007). Only the OMI-TOMS overpass product is used in the present work and available online via http://avdc.gsfc.nasa.gov/pub/data/satellite/Aura/ OMI/V03/L2OVP/. These products are retrieved using two wavelengths ( 317.5 and $331.2 \mathrm{~nm}$ under most conditions, while 331.2 and $360 \mathrm{~nm}$ are used for high ozone and high solar zenith angles). The precision of OMI-TOMS is evaluated at $3 \%$. For more information on the OMI instrument, the reader may refer to the OMI Algorithm Theoretical Basis Document Volume II (Bhartia, 2002).

\subsection{Dobson and SAOZ spectrometers}

Historically, the Dobson spectrometer is the first developed instrument dedicated to TCO measurements. The Antarctic ozone hole was observed for the first time by a Dobson instrument (Farman et al., 1985); its operating principle is based on the differential absorption method in the ultraviolet Huggins band, where ozone exhibits strong absorption features. Total ozone observation is performed with the Dobson spectrophotometer by measuring the relative intensities of selected pairs of ultraviolet wavelengths. The most used are the double pair $(305.5 / 325.5$ and $317.6 / 339.8 \mathrm{~nm}$, and $311.45 / 332.4$ and $316.6 / 339.8 \mathrm{~nm}$ ) emanating from the sun, moon or zenith sky (WMO, 2008, 2003). Currently, the Dobson measurements network is composed of more than 80 stations around the world and the instruments used are calibrated with the reference standard D 83 as recognized by ESRL (Earth System Research Laboratory) and WMO (World Meteorological Organisation). The Dobson network stations selected for the purpose of this study are Marcapomacocha, Irene, Springbok, Melbourne and Buenos Aires. The relative uncertainty linked to this instrument is estimated to be around 2\% (Basher, 1985). Further information regarding the Dobson instrument can be found in the study by Komhyr et al. (1989 and 1993).

The SAOZ instrument was developed by CNRS (Centre National de la Recherche Scientifique) in the late 1980s after the ozone hole discovery. It was used for the first time in Antarctica to measure ozone during the polar winter. SAOZ operates in the visible and ultraviolet spectral bands in which it measures the sunlight scattered from the zenith sky in the wavelength range between 300 and $600 \mathrm{~nm}$. The spectral resolution value is evaluated to be $0.8 \mathrm{~nm}$ (Hendrick et al., 2011). The SAOZ instrument is dedicated to measure total ozone and nitrogen columns under a solar zenith angle (SZA) up to $91^{\circ}$. In this paper, the TCO obtained from the SAOZ is recorded over Bauru (Brazil) and Réunion Island (France) stations. The SAOZ observations are performed during sunrise and sunset with a precision of 3 and $5 \%$, respectively. The daily average is taken as the mean of sunrise and sunset measurements. Hendrick et al. (2011) have shown that use of $\mathrm{O}_{3}$ AMF based on the TOMS $\mathrm{O}_{3}$ climatology improves the comparison between the Dobson, Brewer, and SAOZ total ozone measurements. After applying these new AMF values to $\mathrm{SAOZ}$ and correcting the satellites for temperature and SZA dependencies, the amplitude of the seasonal difference between them and SAOZ decreases to less than 2-4\% at midlatitude and in the tropics. These new AMF values have been used since the release of version V2 of SAOZ data reprocessing. Pastel et al. (2014) found a bias between SAOZ and OMI-TOMS of up to $9.4 \%$ at Bauru and $1.3 \%$ at Réunion Island. More details about the SAOZ instrument and its various features are documented by Pommereau and Goutail (1988).

\section{Method of analyses}

In this work, IASI TCO monthly means are compared with data from OMI satellite and from ground-based observations using statistical descriptive methods. This is a common method for ozone data validation which consists of comparing the monthly and seasonal variation of ozone under validation with respect to measurements from other instruments. The comparison study is performed on the temporal and spatial distribution of data. The comparison indexes used are the relative difference (RD), the bias error (BE), the relative and absolute root mean square (RMS) and the correlation coefficient $R^{2}$ between measurements. The relative difference $\mathrm{RD}$ between the TCO measurement of the IASI and another instrument (called $I$ ) for a given month " $m$ " is calculated for a specific location following the expression:

$\mathrm{RD}_{\mathrm{m}}=100 \times \frac{\text { IASI }_{\mathrm{m}}-I_{\mathrm{m}}}{I_{\mathrm{m}}}$,

where $I_{\mathrm{m}}$ represents the monthly mean value of the considered instrument. The mean bias errors are taken as the relative difference average values and are calculated as follows:

$\mathrm{BE}=\frac{1}{N} \sum_{\mathrm{m}=1}^{N} \mathrm{RD}_{\mathrm{m}}$

The relative root mean square is calculated with respect to the instrument $(I)$, and its expression is given by

$\mathrm{RMS}_{r}=\sqrt{\frac{1}{N} \sum_{\mathrm{m}=1}^{N}\left(\mathrm{RD}_{\mathrm{m}}\right)^{2}}$, 

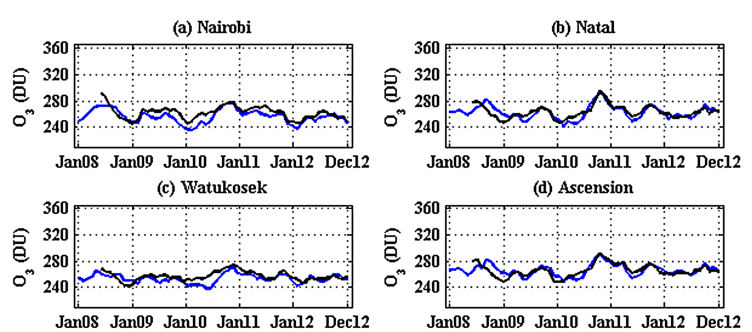

(e) Marcapomacocha

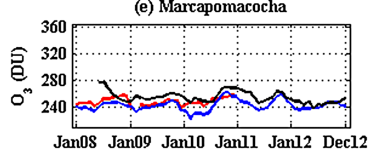

(g) Fiji

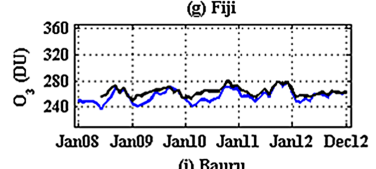

(i) Bauru

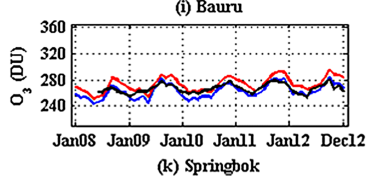
(k) Springok

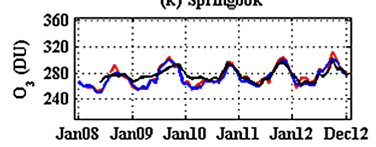
(m) Melbourne
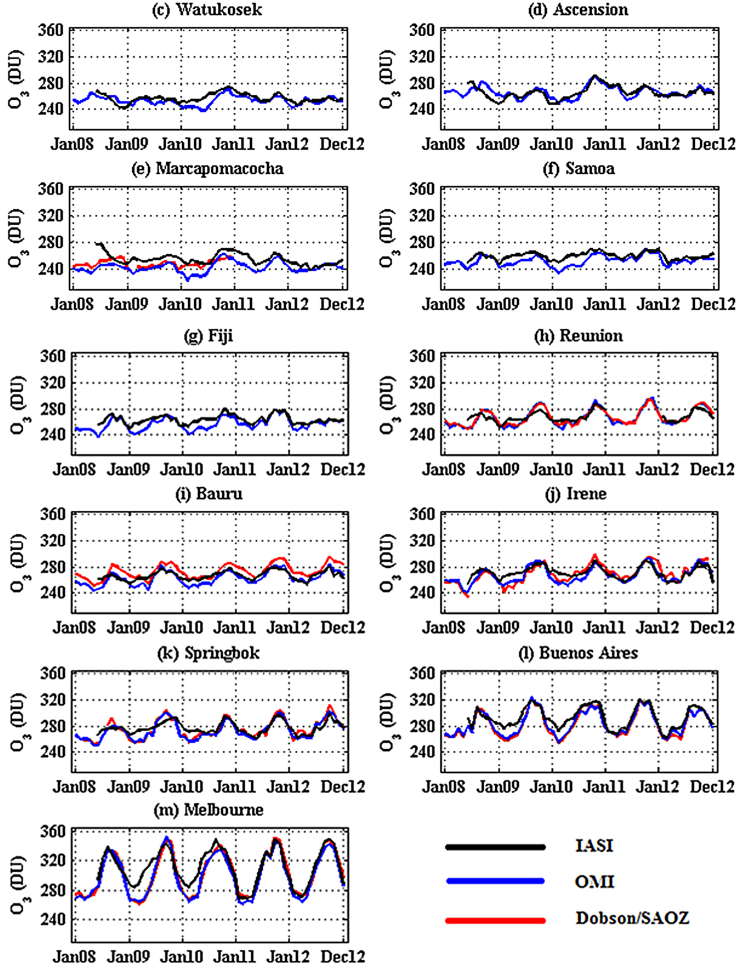

(f) Samoa

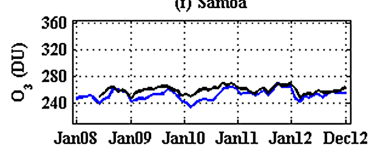

(h) Reunion

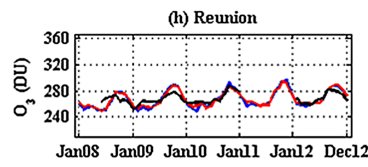

(j) Irene
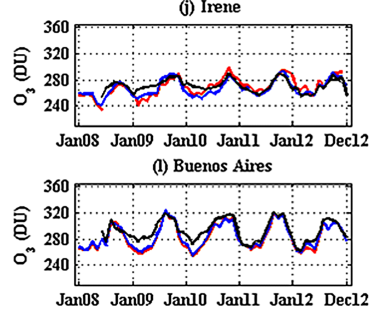

Jan0S Jan09 Jan10 Janl1 Janl2 Dec12

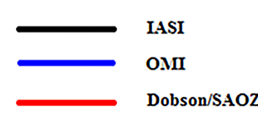

Figure 2. Comparison of the monthly mean TCO observed from July 2008 to December 2012 by IASI with OMI-TOMS, Dobson (over five stations) and SAOZ (over Réunion and Bauru stations). Graphics are numbered per station from (a) to $(m)$. Station names and location are indicated at the top of each graph.

where $N$ represents the number of month-pairs between IASI and the considered instrument. The correlation between IASI and another instrument is assessed by linear regression method.

\section{Results and discussion}

\subsection{Comparison of TCO from IASI with the other instruments}

Comparisons between IASI and other instruments are based on the monthly averaged TCO values derived for each instrument for the period of July 2008 to December 2012. The obtained RD, BE and RMS results are presented in Table 1, while the overlapping of monthly averages from each instrument is plotted in Fig. 2. Regarding comparison between satellite measurements overpasses over the 13 stations, there is a good agreement between IASI and OMI which is pronounced by an average bias of $1.83 \%$. In addition, TCO from IASI is slightly higher with respect to OMI for all sta-

tions, except over Ascension Island where OMI is $0.12 \%$ higher than IASI. On the other hand, IASI measurements are significantly overestimated at Marcapomacocha. About $75 \%$ of IASI monthly mean values recorded over the Marcapomacocha station are higher compared to those of the OMI instrument. In addition, the absolute RMS is the highest (12.12 DU; Dobson unit) in comparison to other stations. When removing the Marcapomacocha data from the 13 stations, the average absolute RMS between IASI and OMI is estimated to be $\sim 6.5 \mathrm{DU}$. The best agreement is observed over Fiji station and southward stations. The correlation coefficient $\left(R^{2}\right)$ recorded between IASI and OMI observations for individual sites is observed to be higher than 0.83 from $15^{\circ} \mathrm{S}$ southward. The best correlation is recorded at Melbourne (site located near the mid-latitude region) with a correlation coefficient of 0.94 . In summary, this study shows that agreement between IASI and OMI over subtropical region increases with increasing latitude from the tropics in a southward direction. These observations are consistent with those reported by Boynard et al. (2009), which were obtained by comparing IASI and SAGE II (nadir view at UVvisible band) TCO on a global scale. Boynard et al. (2009) obtained a positive bias of approximately $3 \%$ with respect to IASI and a correlation coefficient higher than 0.9 between IASI and SAGE II over the mid-latitude region. In the present study, the weakest agreement is observed at stations located between 7 and $15^{\circ} \mathrm{S}$. The weaker agreement observed in this tropical band may be linked to cloud effects on the data retrieval process (see Sect. 2.1.3). Otherwise the bias between OMI and IASI is basically due in part to the different characteristics according to the vertical and horizontal resolution of each instrument, and the bias which can be associated with the existing differences between UVvisible and infrared spectroscopy used in the retrieval processes. In a previous study, Antón et al. (2011) compared the ULB/LATMOS IASI $\mathrm{O}_{3}$ product with ozone data from GOME (UV-visible band) instrument over the Iberian Peninsula (north subtropical region near the mid-latitude region). In their study, they obtained a good correlation between IASI and GOME over the Iberian Peninsula which is consistent with that obtained between IASI and OMI over Buenos Aires and Melbourne (subtropical sites near the mid-latitude region); this is presented above in Table 1 . However, a mean relative difference of about $\pm 6 \%$ was observed between IASI and GOME which could be related to the bias between UV-visible and infrared spectroscopy used in the retrieval process (Antón et al., 2011). Others source of discrepancy could probably be due to the existing difference between IASI and OMI in terms of length of observation and spatial resolution $(13 \mathrm{~km} \times 24 \mathrm{~km}$ for OMI and circular pixel of $12 \mathrm{~km}$ diameter for the case of IASI). The IASI and OMI instruments observe the same location on the Earth at different times because of their different equator crossing times (IASI orbits in the morning with a 09:30 equator crossing time and OMI orbits in the afternoon with a 13:10 equator crossing 
(a) Reunion

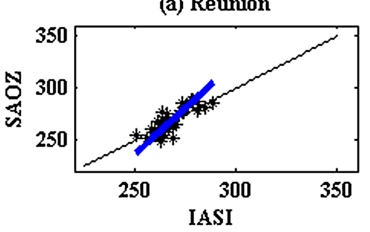

(c) Irene

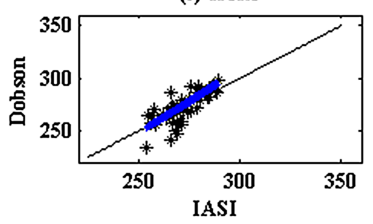

(e) Buenos Aires

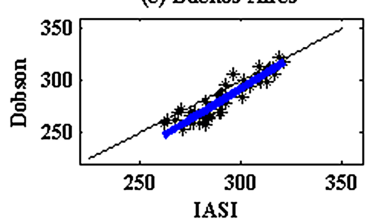

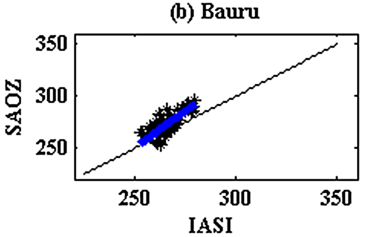

(d) Springbok

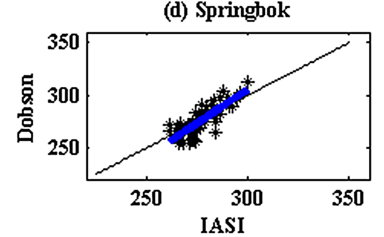

(f) Melhourne

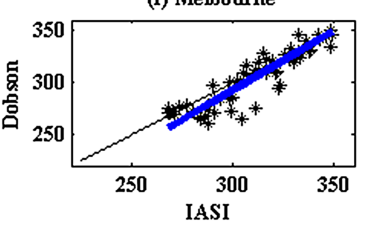

Figure 3. Scatter plot between IASI, Dobson at four sites (Irene, Springbok, Melbourne and Buenos Aires) and SAOZ at two sites (Réunion and Bauru). The black line represents the zero bias line, while the bold blue line represents the median regression line between the two observations.

time). These differences could contribute to the relative difference observed between measurements.

The comparison study between IASI and the ground-based spectrometers (Dobson and SAOZ) reveals good agreement over the subtropical region as well. The mentioned results indicate that the comparison of IASI with Dobson over five stations (Marcapomacocha in the tropics and Irene, Springbok, Melbourne, Buenos Aires in the subtropics) revealed an average bias and RMS of $1.89 \%$ and 8.68 DU (3.22\%), respectively, with respect to Dobson measurements. As mentioned above, IASI agrees better with the other instruments in the subtropics than the tropics. When isolating the Marcapomacocha station (tropical site) from our data, the average bias between IASI and Dobson is reduced to about $1.49 \%$ and the RMS is obtained to be approximately 8.36 DU $(2.85 \%)$. In addition, the average correlation coefficient in the subtropics is estimated to be about 0.86 . Similar results were noted by Viatte et al. (2011) in their comparison study between an IASI $\mathrm{O}_{3}$ LISA product and TCO daily average recorded from a Brewer instrument at Izaña station (north subtropical station, $28.18^{\circ} \mathrm{N}$ ) in the year 2009 . The LISA product is retrieved using an analytical approach based on an "altitude-dependent algorithm" (Eremenko et al., 2008). Viatte et al. (2011) showed that IASI observations are $1.50 \%$ higher than Brewer, and the correlation coefficient between the two observations is estimated to be 0.89 in their study.

The results of comparison between IASI and Dobson over the subtropics are somewhat similar to those obtained between IASI and OMI satellites which were presented earlier in the present document. However, it should be mentioned

that some minor different features were identified. In order to give additional details on IASI observation behaviour with respect to Dobson and SAOZ instruments over the subtropical region, median regression between IASI and Dobson was performed. The obtained scatter plots are presented on Fig. 3. The black solid line indicates the zero bias (unit slope) while the blue line is the regression median line between the two measurements. The scatter plots are from the monthly mean data recorded between June 2008 and December 2012. From Fig. 3, it is apparent that IASI overestimates the Dobson instrument at Melbourne and Buenos-Aires (two stations located beyond $34^{\circ} \mathrm{S}$ ) compared to Springbok and Irene (South African sites). Indeed $92 \%$ of the projected scatter plots at Buenos Aires are above the unit slope. A similar feature is also observed in the case of Melbourne station. Regression median line fits the slope better in the case of Springbok and Irene (two stations located between 25 and $30^{\circ} \mathrm{S}$ ) indicating a small bias between IASI and Dobson in these two sites in comparison with Melbourne and Buenos Aires (two stations located beyond $34^{\circ} \mathrm{S}$ ). In Table 1 , it is observed that the average bias between IASI and Dobson is less than $0.5 \%$ over South African sites but higher than $2 \%$ in the stations near mid-latitude (Melbourne and Buenos Aires). The correlation coefficients recorded between IASI and Dobson at Melbourne and Buenos Aires are observed to be the highest. In summary, this study reveals the weaker biases over the subtropics between IASI and Dobson in stations near the tropics (Irene and Springbok) while the highest correlation is observed in stations near the mid-latitude region (Buenos Aires and Melbourne). Similar observations were also reported by Antón et al. (2011) where they compared the ULB/LATMOS $\mathrm{O}_{3}$ IASI products with the Brewer instrument over two stations (Coruña and Zaragoza) located on the Iberian Peninsula. Indeed the Coruña station is located at $37.06^{\circ} \mathrm{N}$ (subtropical site near the tropics) while Zaragoza station is located at $41.01^{\circ} \mathrm{N}$ (site near the mid-latitude region). The bias observed by Antón et al. (2011) between IASI and the Brewer instrument at Coruña was $3.68 \%$, whilst that of Zaragoza was observed to be $4.59 \%$. On the other side, Antón et al. (2011) reported that the correlation coefficient between IASI and the Brewer instrument over Zaragoza was the highest (0.94), whilst that of Coruna was reported to be 0.91 . When comparing the bias values of each subtropical site with Dobson observations, it is noted that biases values of Melbourne and Buenos Aires are somewhat similar while the same applies for the observed biases in the South African sites, indicating the capability of IASI and the Dobson instrument to capture the $\mathrm{O}_{3}$ behaviour on latitudinal distribution, the consistency and low variability of Dobson observations and IASI.

Regarding SAOZ observations over Réunion Island and Bauru stations, a good agreement with the IASI instrument is also observed in this study. The SAOZ observations fit well with OMI overpasses over Réunion Island and both instruments slightly underestimate in comparison with IASI. Con- 

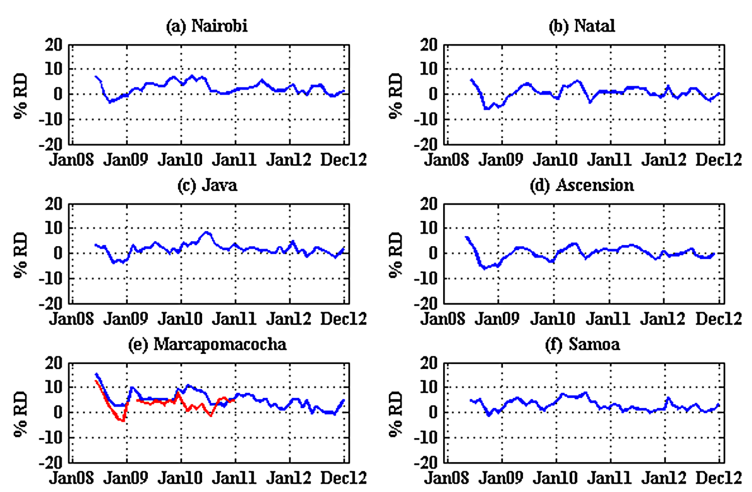

(g) Fiji

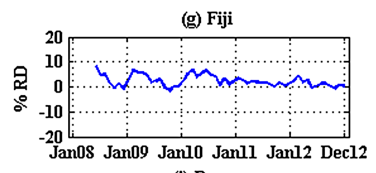

(i) Bauru

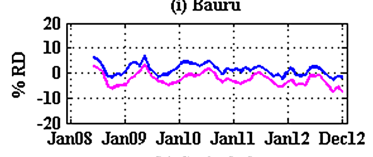
(k) Springhok
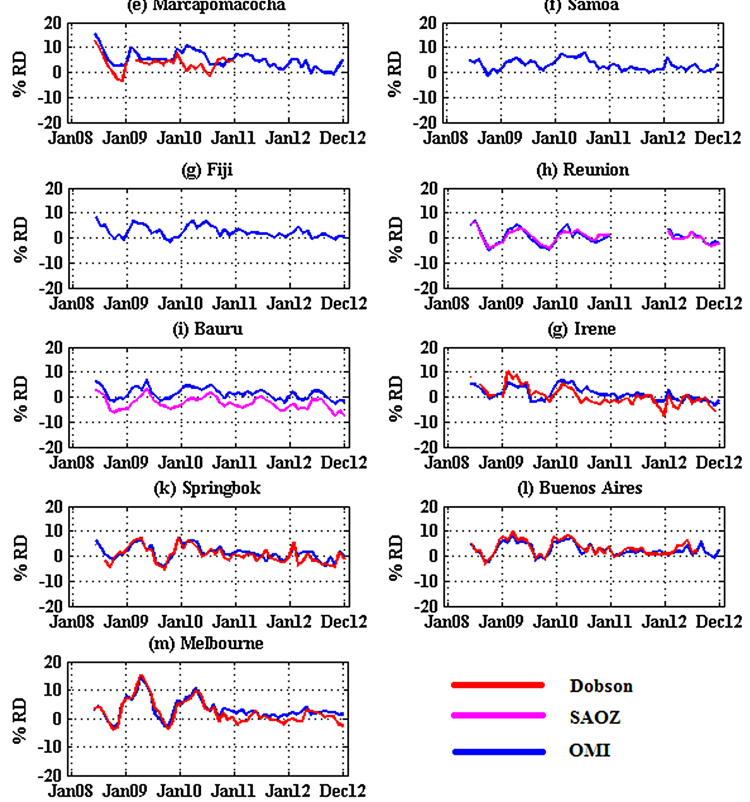

(h) Reunion
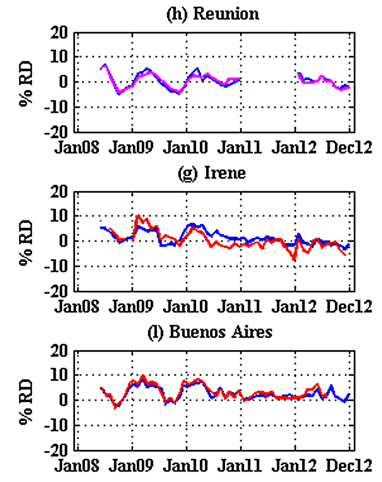

Jan0S Jan09 Jan10 Janll Janl2 Decl2

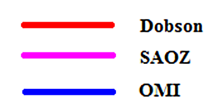

Figure 4. Monthly relative differences (\% RD) of TCO observed from June 2008 to December 2012 between IASI and the other instruments (OMI (13 stations), Dobson (five stations) and SAOZ (two stations)).

trarily, at Bauru, IASI underestimates with a negative bias of $-2.65 \%$ and an RMS of $3.05 \%$ (8.42 DU) lower than SAOZ. It is apparent from Fig. 3 that the median regression line is above the unit slope line for the case of Bauru. Similar results were reported by Pastel et al. (2014) in their comparison study between SAOZ and satellite data over Bauru. In their results they reported a bias of $2.04 \%$ between $\mathrm{SAOZ}$ and the satellite data set.

In order to quantify the variations between IASI and the other instruments, relative differences between instruments were computed using Eq. (1). The obtained results are shown in Fig. 4. The computed relative differences reveal an oscillating trend with decreasing amplitude with increasing time, with an upward trend in autumn and a downward trend in the spring period, especially between June 2008 and August 2010. The upward trends recorded in autumn are observed to reach $9 \%$ over the tropics and $14 \%$ for the subtropical stations, while the negative trend observed during the spring period remains low and may rarely reach $4 \%$.

In Fig. 4, it is observed that the upward trend observed in autumn is strongly reduced from September 2010 due to changes adopted by the level 2 IASI retrieval algorithm (see Sect. 2.1.3). As from 14 September 2010, significant changes have been introduced to surface emissivity calculations and the method adopted for ozone profile retrieval. These significant changes characterize the L2 PPF ozone version 5 (v5) data. It is worth noting that from September 2010 the detection cloud tests have been reinforced in order to reduce the probability of cloud contamination on ozone retrieval process. This could be the reason why the relative difference between IASI and the other instruments is high between June 2008 and August 2010 compared to the period of September 2010 to December 2012 (see Fig. 4). The remaining biases observed between IASI and the others instruments after September 2010 may probably be due to precision associated to each measurement which differs from one instrument to another, the differences existing between the characteristics of each instrument (see Sect. 2), and the time of observation which vary from one instrument to another in the same location. The IASI and OMI measurements are achieved in different times for the same location as the ground-based spectrometer instruments. The precision of TCO data used varies from one instrument to another and can produce a source of relative difference between measurements. On the other hand, the procedure followed to calculate daily measurement differs from one instrument to others and may contribute to the observed biases. However, the biases recorded after September 2010 are low and statistically insignificant compared to those observed before the new algorithm adoption, confirming the high performance of the algorithm used for the ozone version $\mathrm{v} 5$ data retrieval.

\subsection{Seasonal analysis}

In this study, a seasonal distribution comparison between IASI and the other instruments was also performed. The seasons are defined as follows: DJF (December, January and February), MAM (March, April and May), JJA (June, July and August) and SON (September October and November) to represent austral summer, autumn, winter and spring, respectively. The aim of this analysis was to quantify the observed seasonal dependence of IASI records with respect to other instruments. Thus, biases between IASI and the other instruments from all sites were merged and calculated per season. The obtained results are presented in Table 2. Effectively, IASI measurements exhibit a seasonal dependence with an upward trend in autumn (MAM) and a downward trend during the spring (SON) period. The distribution pattern of seasonal bias between IASI and each instrument follows the same cycle. The observed cycle can be described as follows: a positive bias with a positive gradient is observed between summer (DJF) and autumn, and the cycle declines slightly during the winter period, up until it reaches its minimum values during spring. A negative bias higher than $2 \%$ between IASI and SAOZ is recorded during the spring period, presumably due to Bauru SAOZ measurements which 
Table 2. Seasonal biases observed between IASI and the other instruments (OMI, Dobson and SAOZ), merged for all sites.

\begin{tabular}{l|ll|rr|rr}
\hline$\%$ bias $(1 \sigma)$ & \multicolumn{2}{|c|}{ OMI } & \multicolumn{2}{c|}{ DOBSON } & \multicolumn{2}{c}{ SAOZ } \\
\hline & $\begin{array}{l}\text { All data } \\
(2008-2012)\end{array}$ & $\begin{array}{l}\text { From September } \\
\text { 2010 to the end }\end{array}$ & $\begin{array}{r}\text { All data } \\
(2008-2012)\end{array}$ & $\begin{array}{r}\text { From September } \\
\text { 2010 to the end }\end{array}$ & $\begin{array}{r}\text { All data } \\
(2008-2012)\end{array}$ & $\begin{array}{r}\text { From September } \\
2010 \text { to the end }\end{array}$ \\
\hline DJF & $2.47(2.00)$ & $1.98(1.76)$ & $1.14(2.34)$ & $-0.78(2.03)$ & $-1.10(2.70)$ & $-0.53(1.97)$ \\
MAM & $3.86(1.87)$ & $2.18(1.58)$ & $3.46(2.31)$ & $0.67(1.80)$ & $2.18(2.40)$ & $0.47(1.12)$ \\
JJA & $3.05(1.71)$ & $1.62(1.59)$ & $1.53(2.16)$ & $0.57(1.73)$ & $2.03(3.80)$ & $1.25(0.90)$ \\
SON & $0.66(1.90)$ & $0.52(1.48)$ & $-0.82(1.90)$ & $-1.4(1.72)$ & $-2.38(3.37)$ & $-1.56(1.57)$ \\
Annual & $2.51(1.87)$ & $1.57(1.60)$ & $1.32(2.17)$ & $-0.23(1.82)$ & $0.73(3.08)$ & $-0.10(1.39)$ \\
\hline
\end{tabular}

are actually overestimated. One should keep in mind that there is no seasonal bias higher than $4 \%$. In addition, seasonal and annual biases are reduced from September 2010 onwards (see Table 2). Figure 5 presents the monthly distributions of relative differences and the associated standard deviations observed between IASI and different instruments (a) before and (b) after the adoption of a new version (L2 PPF version v5). The seasonal variation of relative difference is high before the adoption of the L2 PPF version v5. Figure 5a showed a maximum amplitude of around $6 \%$ during the ascending phase of the annual cycle, especially in the case of OMI and Dobson. The observed ascending phase is reduced after the adoption of version 5, and significant improvements are recorded between December and April (see Fig. 5b). It can be noted that the period between December and April is marked by cyclonic activity and deep convection in the southern tropics and subtropics; the decrease of bias between IASI and the other instruments in this period could partly be a result of changes made to the cloud detection algorithm and surface emissivity incorporated in the retrieval process. These changes have led to improvement in the final PPF v5 product quality. The downward trend of IASI measurements observed in each spring period is lower than $4 \%$ for the whole time of observations (June 2008-December 2012). When version v5 is adopted, the observed bias due to the autumn upward trend is dramatically reduced, then the agreement between IASI and the others instruments is excellent. The monthly average of relative differences observed during the period after August 2010 is within $\pm 3 \%$ (see Fig. 5b).

Table 2 presents seasonal biases recorded between IASI and each instrument. Two separated columns are presented for each instrument, with the left column showing the obtained seasonal biases for the complete time of observation (June 2008-December 2012), and the right column presenting the seasonal bias recorded from September 2010 to December 2012. In this table, it is observed that the seasonal bias distribution has kept the same pattern of variation during a complete annual cycle. Also, it is observed that the recorded values after August 2010 are the lowest. A good agreement between IASI and the other instruments is observed after August 2010, and the obtained annual bias is less
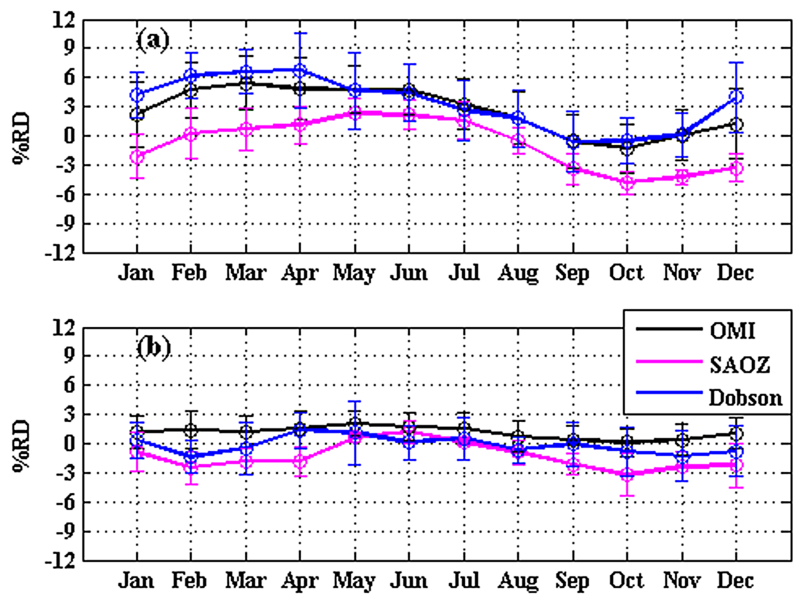

Figure 5. Monthly distribution of relative differences recorded between IASI and the other instruments (OMI SAOZ and Dobson): (a) from June 2008 to August 2010 and (b) from September 2010 to December 2012. The error bar is the standard deviation associated with the monthly mean distribution.

than $1.6 \%$ with OMI and less than $\pm 1 \%$ with the groundbased instruments (SAOZ and Dobson).

\subsection{Latitudinal distribution analysis}

The TCO latitudinal distribution analysis has been made by grouping the stations by $5^{\circ}$ latitude bands from the equator in a southward direction (i.e. data from stations located between $0^{\circ}$ and $5^{\circ}$ are merged). The same merging is done for stations located in the $5-10^{\circ} \mathrm{S}, 10-15^{\circ} \mathrm{S}, 15-20^{\circ} \mathrm{S}, 20-25^{\circ} \mathrm{S}$, $25-30^{\circ} \mathrm{S}, 30-35^{\circ} \mathrm{S}$ and $35-40^{\circ} \mathrm{S}$ latitude bands. In the end, eight station latitude bands were formulated from Nairobi $\left(-1.27^{\circ} \mathrm{S}\right)$ to Melbourne $\left(37.80^{\circ} \mathrm{S}\right)$. More details about each station latitudinal position are presented in Table 1. TCO annual means and its associated standard deviations were calculated for each latitude band. The latitudinal evolution of TCO for all instruments is shown in Fig. 6. Positive bias is apparent between IASI and the other instruments except in the $20-25^{\circ} \mathrm{S}$ latitude band where SAOZ is slightly higher due to Bauru SAOZ observations which are actually overestimated in comparison with OMI and IASI. It is worth noting 


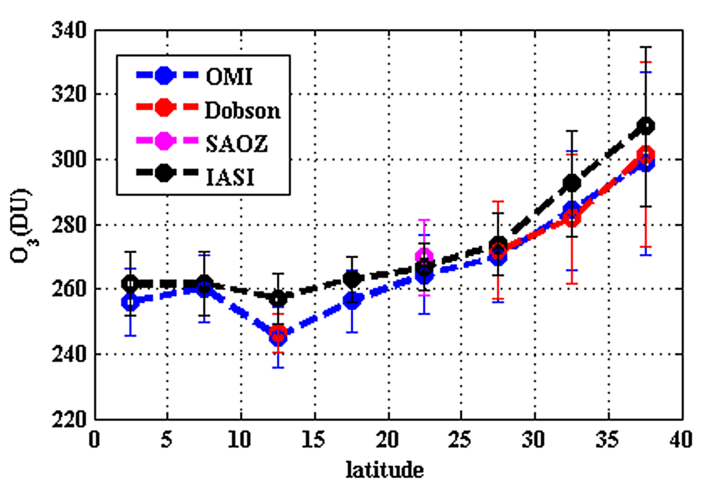

Figure 6. Latitudinal distribution of TCO and its associated standard deviation observed for each instrument.

that the observed positive bias between IASI and other instruments in the latitudinal distribution is less than $4 \%$ and the maximum is recorded in the $10-15^{\circ} \mathrm{S}$ latitude band. The correlation coefficient obtained on latitudinal distribution between IASI and the other instruments is higher than 0.96. IASI observations indicate an RMS of $6.48 \mathrm{DU}(2.1 \%)$ with Dobson and 7.30 DU (2.8\%) with the OMI satellite in this latitudinal distribution. The behaviour of latitudinal distribution seems to indicate a similar pattern in all the stations. A smaller TCO variability is observed over the tropics in comparison with the subtropical region. This variability is estimated based on the error bar associated with the latitudinal mean value. It is clearly observed (Fig. 6) that the variability increases from the tropics to the mid-latitude region. However, it should be mentioned that IASI has a low variability compared to the observed variability derived from OMI and ground-based instruments.

\section{Conclusions}

In this paper, we examined TCO monthly mean for the validation of IASI, recorded between June 2008 and December 2012 over 13 tropical and subtropical sites comparing ozone data from the OMI/aura satellite, Dobson spectrophotometer and the SAOZ ground-based spectrometer. It is worth noting that the examined data product in this work is the IASI level 2 PPF developed by the ISSWG under EUMETSAT supervision. The agreement between TCO from IASI and the above-mentioned instruments is excellent, especially over sites located $15^{\circ} \mathrm{S}$ in a southward direction where an average correlation coefficient higher than 0.87 is reported between IASI and OMI, and higher than 0.83 with groundbased instruments. In addition, this study indicates that IASI slightly overestimates TCO compared to OMI and Dobson observations, with a bias of less than $2 \%$, and on the other side, underestimates TCO compared to $\mathrm{SAOZ}$ measurements over Bauru, with a bias of $2.63 \%$. IASI seasonal dependence is also identified, and is characterized by an upward trend in autumn and a downward trend during the spring season.
The retrieval algorithm of IASI L2 products has improved since the release of version 5 of the data product in September 2010. The version 5 data product seems to agree very well with TCO from the other instruments in comparison to version 4 , and the seasonal biases recorded with the $\mathrm{L} 2$ version 5 are effectively reduced. IASI bias error recorded after September 2010 was observed to be less than $1.6 \%$ with respect to OMI, and less than $\pm 1.0 \%$ annual mean with respect to ground-based observations. From these analyses, we conclude that ozone from IASI recorded after September 2010 presents low uncertainties and can be used as a reference product for future analysis to carry on long-term variability of TCO in the southern tropics and subtropics or can be merged with correlative data from satellites such as OMI to provide a high-quality and reliable ozone data set.

Author contributions. A. M. Toihir is the principal investigator of the present study; H. Bencherif and V. Sivakumar were the supervisor and co-supervisor of his doctoral degree, respectively, and participated in interpretation of the results. In addition to that, they are coordinators of the Atmospheric Research Southern Africa and Indian Ocean (ARSAIO) program. L. El Amraoui provided the IASI data and contributed to the review of manuscript. N. Mbatha and T. Portafaix contributed to data analysis and the review of the manuscript.

Acknowledgements. The present work is supported by LACy and the GDRI ARSAIO (Atmospheric Research in Southern Africa and the Indian Ocean), a French-South African co-operative programme network supported by the French Centre National de la Recherche Scientifique (CNRS) and the South Africa National Research Foundation (NRF).

The authors acknowledge the European Community, the Région Réunion, the CNRS, and the Université de La Réunion for their support and contribution in the construction phase of the research infrastructure OPAR (Observatoire de Physique de l'Atmosphère à La Réunion). OPAR and LACy are presently funded by CNRS (INSU) and Université de La Réunion, and managed by OSU-R (Observatoire des Sciences de l'Universà la Réunion, UMS 3365). We acknowledge A. Pazmino in charge of the SAOZ Network and J.-M. Metzger (LACy, Réunion).

The first author (A. M. Toihir) acknowledges the Indian Ocean Bureau of AUF (Agence Universitaire de la Francophonie) and the University of KwaZulu Natal for travel and hosting under invited student exchange in the above NRF-CNRS bilateral research project (UID 68668). The authors are thankful to the Canada WOUDC team, which is under the auspices of WMO and OMI, for providing access to data via their website. The authors also acknowledge the ETHER database team (CNES and INSU-CNRS) for producing and archiving the IASI product.

The topical editor C. Jacobi thanks A. Sarkissian and one anonymous referee for help in evaluating this paper. 


\section{References}

Amato, U., Masiello, G., Serio, C., and Viggiano, M.: The $\sigma$-IASI code for the calculation of infrared atmospheric radiance and its derivatives, Environ. Modell. Softw., 17, 651-667, 2002.

Antón, M., Loyola, D., Clerbaux, C., López, M., Vilaplana, J. M., Bañón, M., Hadji-Lazaro, J., Valks, P., Hao, N., Zimmer, W., Coheur, P. F., Hurtmans, D., and Alados-Arboledas, L.: Validation of the MetOp-A total ozone data from GOME-2 and IASI using reference ground-based measurements at the Iberian Peninsula, Remote Sens. Environ., 115, 1380-1386, 2011.

August, T., Klaes, D., Schlüssel, P., Hultberg, T., Crapeau, M., Arriaga, A., O'Carroll, A., Coppens, D., Munro, R., and Calbet, X.: IASI on Metop-A: Operational Level 2 retrievals after five years in orbit, J. Quant. Spectrosc. Ra., 113, 1340-1371, doi:10.1016/j.jqsrt.2012.02.028, 2012.

Balis, D., Kroon, M., Kououli, M. E., Labow, G., Veefkind, J. P., and McPeters, R. D.: Validation of Ozone Monitoring Instrument total ozone column measurements using Brewer and Dobson spectrophotometer ground based observations, J. Geophys. Res., 112, D24S46, doi:10.1029/2007JD008796, 2007a.

Balis, D., Lambert, J.-C., Van Roozendael, M., Spurr, R., Loyola, D., Livschitz, Y., Valks, P., Amiridis, V., Gerard, P., Granville, J., and Zehner, C.: Ten years of GOME/ERS2 total ozone data the new GOME data processor (GDP) version 4: 2. Groundbased validation and comparisons with TOMS V7/V8, J. Geophys. Res., 112, D07307, doi:10.1029/2005JD006376, 2007b.

Barret, B., Le Flochmoen, E., Sauvage, B., Pavelin, E., Matricardi, M., and Cammas, J. P.: The detection of post-monsoon tropospheric ozone variability over south Asia using IASI data, Atmos. Chem. Phys., 11, 9533-9548, doi:10.5194/acp-11-95332011, 2011.

Basher R. E.: Review of the Dobson Spectrometer and its accuracy in atmospheric ozone, edited by: Zerefos C. S. and Ghazi, A. Ozone symposium, Greece, 387-388, 1985.

Bencherif, H., El Amraoui, L., Semane, N., Massart, S., Charyulu, D. V., Hauchecorne, A., and Peuch, V.-H.: Examination of the 2002 major warming in the southern hemisphere using groundbased and Odin/SMR assimilated data: stratospheric ozone distributions and tropic/mid-latitude exchange, Can. J. Phys., 85, 1287-1300, 2007.

Bencherif, H., El Amraoui, L., Kirgis, G., Leclair, de Bellevue J., Hauchecorne, A., Mzé, N., Portafaix, T., Pazmińo, A., and Goutail, F.: Analysis of a rapid increase of stratospheric ozone during late austral summer 2008 over Kerguelen $\left(49.4^{\circ} \mathrm{S}\right.$, 70.3 ${ }^{\circ}$ E), Atmos. Chem. Phys., 11, 363-373, doi:10.5194/acp11-363-2011, 2011.

Bhartia, P. K.: OMI Algorithm Theoretical Basis Document Volume II, OMI Ozone Products, ATBD-OMI-02, Version 2.0, 2002.

Boynard, A., Clerbaux, C., Coheur, P.-F., Hurtmans, D., Turquety, S., George, M., Hadji-Lazaro, J., Keim, C., and MeyerArnek, J.: Measurements of total and tropospheric ozone from IASI: comparison with correlative satellite, ground-based and ozonesonde observations, Atmos. Chem. Phys., 9, 6255-6271, doi:10.5194/acp-9-6255-2009, 2009.

Bracher, A., Lamsal, L. N., Weber, M., Bramstedt, K., ColdeweyEgbers, M., and Burrows, J. P.: Global satellite validation of SCIAMACHY $\mathrm{O}_{3}$ columns with GOME WFDOAS, Atmos. Chem. Phys., 5, 2357-2368, doi:10.5194/acp-5-2357-2005, 2005.
Bramstedt, K., Gleason, J., Loyola, D., Thomas, W., Bracher, A., Weber, M., and Burrows, J. P.: Comparison of total ozone from the satellite instruments GOME and TOMS with measurements from the Dobson network 1996-2000, Atmos. Chem. Phys., 3, 1409-1419, doi:10.5194/acp-3-1409-2003, 2003.

Calbet, X. and Schlüssel, P.: Technical note: analytical estimation of the optimal parameters for the EOF retrievals of the IASI Level 2 Product Processing Facility and its application using AIRS and ECMWF data, Atmos. Chem. Phys., 6, 831-846, doi:10.5194/acp-6-831-2006, 2006.

Calbet, X., Schlüssel, P., Hultberg, T., Phillips, P. and August, T.: Validation of the operational IASI level 2 processor using AIRS and ECMWF data; Adv. Space Res., 37, 2299-2305, doi:10.1016/j.asr.2005.07.057, 2006.

Clerbaux, C., Boynard, A., Clarisse, L., George, M., Hadji-Lazaro, J., Herbin, H., Hurtmans, D., Pommier, M., Razavi, A., Turquety, S., Wespes, C., and Coheur, P.-F.: Monitoring of atmospheric composition using the thermal infrared IASI/MetOp sounder, Atmos. Chem. Phys., 9, 6041-6054, doi:10.5194/acp-9-6041-2009, 2009.

Dufour, G., Eremenko, M., Griesfeller, A., Barret, B., LeFlochmoën, E., Clerbaux, C., Hadji-Lazaro, J., Coheur, P.-F., and Hurtmans, D.: Validation of three different scientific ozone products retrieved from IASI spectra using ozonesondes, Atmos. Meas. Tech., 5, 611-630, doi:10.5194/amt-5-611-2012, 2012.

Edwards, P. G., Berruti, B., Blythe, P., Callies, J., Carlier, S., Fransen, C., Krutsch, R., Lefebvre, A.-R., Loiselet, M., and Stricker, N.: the MetOp satellite, weather information from Polar orbit, ESA Bulletin No. 127, 8-17, 2006.

El Amraoui, L., Attié, J.-L., Semane, N., Claeyman, M., Peuch, V.H., Warner, J., Ricaud, P., Cammas, J.-P., Piacentini, A., Josse, B., Cariolle, D., Massart, S., and Bencherif, H.: Midlatitude stratosphere - troposphere exchange as diagnosed by MLS $\mathrm{O}_{3}$ and MOPITT CO assimilated fields, Atmos. Chem. Phys., 10, 2175-2194, doi:10.5194/acp-10-2175-2010, 2010.

Eremenko, M., Dufour, G., Foret, G., Keim, C., Orphal, J., Beekmann, M., Bergametti, G., and Flaud, J.-M.: Tropospheric ozone distributions over Europe during the heat wave in July 2007 observed from infrared nadir spectra recorded by IASI, Geophys. Res. Lett., 35, L18805, doi:10.1029/2008GL034803, 2008.

Farman, J. C., Gardiner B. G., and Shanklin J. D.: Large losses of total ozone in Antarctica reveal seasonal $\mathrm{ClOx} / \mathrm{NO}$ interaction, Nature, 315, 207-210, 1985.

George, M. and Clerbeaux, C.: final report: Validation study for IASI trace gas retrievals, LATMOS-CNRS, Université Paris 6, France, 35-54, 2010.

Hendrick, F., Pommereau, J.-P., Goutail, F., Evans, R. D, Ionov, D., Pazmiño, A., Kyrö, E., Held, G., Eriksen, P., Dorokhov, V., Gil, M. and Van Roozendael M.: NDACC/SAOZ UV-visible total ozone measurements: improved retrieval and comparison with correlative ground-based and satellite observations, Atmos. Chem. Phys., 11, 5975-5995, doi:10.5194/acp-11-5975-2011, 2011.

Hurtmans, D., Coheur, P.-F., Wespes, C., Clarisse, L., Scharf, O., Clerbaux, C., Hadji-Lazaro, J., George, M., and Turquety, S.: FORLI radiative transfer and retrieval code for IASI, J. Quant. Spectrosc. Ra., 113, 1391-1408, doi:10.1016/j.jqsrt.2012.02.036, 2012. 
Kahn, B. H., Eldering, A., Ghil, M., Bordoni, S., and Clough S. A.: Sensitivity Analysis of Cirrus Cloud Properties from HighResolution Infrared Spectra, Part I: Methodology and Synthetic Cirrus, J. Climate, 17, 4856-4870, doi:10.1175/JCLI-3220.1, 2004.

Keim, C., Eremenko, M., Orphal, J., Dufour, G., Flaud, J.-M., Höpfner, M., Boynard, A., Clerbaux, C., Payan, S., Coheur, P.-F., Hurtmans, D., Claude, H., Dier, H., Johnson, B., Kelder, H., Kivi, R., Koide, T., López, B. M., Lambkin, K., Moore, D., Schmidlin, F. J., and Stübi, R.: Tropspheric ozone from IASI: comparison of different inversions algorithm and validation with ozonesonde in the northern middle-latitudes, Atmos. Chem. Phys., 9, 93299347, doi:10.5194/acp-9-9329-2009, 2009.

Komhyr, W. D., Mateer, C. L., and Hudson, R. D.: Effective BassPaur 1985 Ozone Absorption Coefficients for Use with Dobson Ozone Spectrophotometers, J. Geophys. Res., 98, 20451-20465, 1993.

Komhyr, W. D., Grass, R. D., and Lenoard, R. K.: Dobson Spectrophotometer 83. A Standard for Total Ozone Measurements, 1962-1987, J. Geophys. Res., 94, 9847-9861, 1989.

Kroon, M., Brinksma, E. J., Labow, G., and Balis, D.: OMTO3 Validation Status 200604, RP-OMIE-KNMI-820, Version 1.1, 1-24, 2006.

Krueger, A., Schoeberl, M., Newman, P. and Stolarski, R.: The 1991 Antarctic ozone hole; TOMS observation, Geophys. Res. Lett., 19, 1215-1218, 1992.

Loveland, T. R., Reed, B. C., Brown, J. F., Ohlen, D. O., Zhu, Z., Yang, L., and Merchant, J. W.: Development of a global land cover characteristics database and IGBP DISCover from $1 \mathrm{~km}$ AVHRR data, Int. J. Remote Sens., 21, 1303-1330, doi:10.1080/014311600210191, 2000.

Massart, S., Clerbaux, C., Cariolle, D., Piacentini, A., Turquety, S., and Hadji-Lazaro, J.: First steps towards the assimilation of IASI ozone data into the MOCAGE-PALM system, Atmos. Chem. Phys., 9, 5073-5091, doi:10.5194/acp-9-5073-2009, 2009.

Matricardi, M.: A principal component based version of the RTTOV fast radiative transfer model, Q. J. Roy. Meteor. Soc., 136, 18231835, doi:10.1002/qj.680, 2010.

McPeters, R. D. and Labow, G. J.: An assessment of the accuracy of 14.5 years of Nimbus 7 TOMS Version 7 ozone data by comparison with the Dobson network, Geophys. Res. Lett., 23, 36953698, 1996.

Pastel, M., Pommereau, J.-P., Goutail, F., Richter, A., Pazmiño, A., Ionov, D., and Portafaix, T.: Construction of merged satellite total $\mathrm{O}_{3}$ and $\mathrm{NO}_{2}$ time series in the tropics for trend studies and evaluation by comparison to NDACC SAOZ measurements, Atmos. Meas. Tech., 7, 3337-3354, doi:10.5194/amt-7-3337-2014, 2014.

Pavelin, E. G., English, S. J., and Eyre J. R.: The assimilation of cloud-affected infrared satellite radiances for numerical weather prediction, Q. J. Roy. Meteor. Soc., 134, 737-749, doi:10.1002/qj.243, 2008.

Pommereau, J. P. and Goutail, F.: $\mathrm{O}_{3}$ and $\mathrm{NO}_{2}$ ground-based measurements by visible spectrometry during Arctic winter and spring 1998, Geophys. Res. Lett., 15, 891-894, 1988.
Portafaix, T., Morel, B., Bencherif, H., Godin-Beekmann, S., Baldy, S., and Hauchecorne, A.: Fine scale study of a thick stratospheric ozone lamina at the edge of the southern subtropical barrier, J. Geophys. Res., 108, 4196-4205, 2003.

Schlüssel, P., Hultberg, T. H., Phillips, P. L., August, T., and Calbet, X.: The operational IASI Level 2 processor, Adv. Space Res., 36, 982-988, doi:10.1016/j.asr.2005.03.008, 2005.

Stolarski, R. S., Schoeberl, M. R., Newman, P. A., McPeters, R. D., and Krueger, A. J.: the 1989 Antarctic ozone hole as observed by TOMS, Geophys. Res. Lett., 17, 1267-1270, 1990.

Turquety, S., Hadji-Lazaro, J., Clerbaux, C., Hauglustaine, D. A., Clough, S. A., Cassé, V., Schlüssel, P., and Mégie, G.: Operational trace gas retrieval algorithm for the Infrared Atmospheric Sounding Interferometer, J. Geophys. Res., 109, D21301, doi:10.1029/2004JD004821, 2004.

UNEP: Handbook for the Montreal Protocol on Substances that Deplete the Ozone Layer ISBN: 9966-7319-0-3, available at: http://www.unep.ch/ozone/publications/MP_Handbook/ MP-Handbook-2009.pdf (last access: 9 September 2015), 2009.

Viatte, C., Schneider, M., Redondas, A., Hase, F., Eremenko, M., Chelin, P., Flaud, J.-M., Blumenstock, T., and Orphal, J.: Comparison of ground-based FTIR and Brewer $\mathrm{O}_{3}$ total column with data from two different IASI algorithms and from OMI and GOME-2 satellite instruments, Atmos. Meas. Tech., 4, 535-546, doi:10.5194/amt-4-535-2011, 2011.

Weber, M., Dikty, S., Burrows, J. P., Garny, H., Dameris, M., Kubin, A., Abalichin, J., and Langematz, U.: The Brewer-Dobson circulation and total ozone from seasonal to decadal time scales, Atmos. Chem. Phys., 11, 11221-11235, doi:10.5194/acp-1111221-2011, 2011.

WMO: Comparison of Total Ozone measurements of Dobson and Brewer spectrophotometers and recommended transfer functions, GAW, 149, 1-35, 2003.

WMO: Operation Handbook Ozone observation with a Dobson Spectrometer, GAW, 183, 1-85, 2008.

WMO/UNEP: assessment, Scientific Assessment of Ozone Depletion, GORMP, report 55, 4.1-4.57, 2014.

Zhou, D. K., Allen, M., Larar, A. M., Liu, X., William, L. Smith, W. L., Strow, L., Yang, P., Schlüssel, P., and Calbet, X.: Global Land Surface Emissivity Retrieved From Satellite Ultraspectral IR Measurements, IEEE Trans. Geosci. Remote Sens., 49, 12771290, doi:10.1109/TGRS.2010.2051036, 2011.

Zhou, D. K., William, L., Smith, W. L., Liu, X., Allen, M., Larar, A. M., Huang, H.-L. A., Li, J., Matthew, J., McGill, M. J., and Mango, S. A.: Thermodynamic and cloud parameter retrieval using infrared spectral data, Geophys. Res. Lett., 32, L15805, doi:10.1029/2005GL023211, 2005.

Zhou, D. K., William, L., Smith, W. L., Liu, X., Allen, M., Larar, A. M., Mango S. A., and Huang H.-L.: Physically Retrieving Cloud and Thermodynamic Parameters from Ultraspectral IR Measurements, J. Atmos. Sci., 64, 969-982, doi:10.1175/JAS3877.1, 2007. 